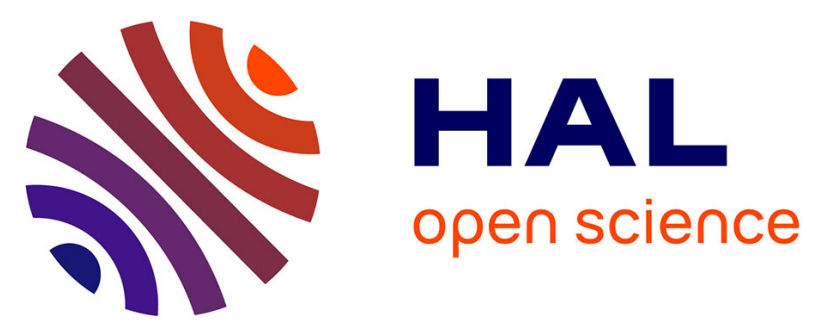

\title{
Atmospheric input of inorganic nitrogen and phosphorus to the Ligurian SEA: Data from the cap Ferrat coastal time-series station
}

Orens Pasqueron de Fommervault, Christophe Migon, Aurélie Dufour, Fabrizio d'Ortenzio, Fayçal Kessouri, Patrick Raimbault, Nicole Garcia, Véronique Lagadec

\section{To cite this version:}

Orens Pasqueron de Fommervault, Christophe Migon, Aurélie Dufour, Fabrizio d'Ortenzio, Fayçal Kessouri, et al.. Atmospheric input of inorganic nitrogen and phosphorus to the Ligurian SEA: Data from the cap Ferrat coastal time-series station. Deep Sea Research Part I: Oceanographic Research Papers, 2015, 106, pp.116-125. 10.1016/j.dsr.2015.08.010 . hal-01194731

\section{HAL Id: hal-01194731 \\ https://hal.sorbonne-universite.fr/hal-01194731}

Submitted on 7 Sep 2015

HAL is a multi-disciplinary open access archive for the deposit and dissemination of scientific research documents, whether they are published or not. The documents may come from teaching and research institutions in France or abroad, or from public or private research centers.
L'archive ouverte pluridisciplinaire HAL, est destinée au dépôt et à la diffusion de documents scientifiques de niveau recherche, publiés ou non, émanant des établissements d'enseignement et de recherche français ou étrangers, des laboratoires publics ou privés. 


\section{Atmospheric input of inorganic nitrogen and phosphorus to the Ligurian Sea: Data from the Cap}

Ferrat coastal time-series station

Orens PASQUERON de FOMMERVAULT ${ }^{(1,2,3, *)}$, Christophe $\operatorname{MIGON}^{(1,2)}$, Aurélie DUFOUR $^{(1,2)}$, Fabrizio D’ORTENZIO ${ }^{(1,2)}$, Fayçal KESSOURI ${ }^{(4)}$, Patrick RAIMBAULT $^{(5)}$, Nicole GARCIA $^{(5)}$, and Véronique LAGADEC ${ }^{(5)}$

1) Sorbonne Universités, UPMC Université Paris 06, UMR 7093, LOV, Observatoire océanologique, F06230, Villefranche-sur-Mer, France

2) CNRS, UMR 7093, LOV, Observatoire Océanologique, F06230, Villefranche-sur-Mer, France

3) ACRI-ST, Sophia-Antipolis, France

4) Université Paul Sabatier, CNRS, Laboratoire d'Aérologie, 14 Avenue Edouard Belin, 31400 Toulouse, France

5) Aix-Marseille Université, CNRS/INSU, Université de Toulon, IRD, Mediterranean Institute of Oceanography (MIO), UM 110, 13288, Marseille, France

* Corresponding author:

Sorbonne Universités, UPMC Université Paris 06, UMR 7093,

LOV, Observatoire océanologique, F06230, Villefranche-sur-Mer, France.

Tel: +33493763986

fax: +33493763739

E-mail address: orens.de-fommervault@obs-vlfr.fr

\section{Abstract}

Atmospheric fluxes of bio-available inorganic nitrogen (DIN, i.e. nitrate + ammonium) and phosphorus (DIP, i.e. phosphate) were measured in 2010, 2011 and 2013 at the sampling station of Cap Ferrat (Ligurian Sea). Wet and dry fluxes of DIN, averaged over three years, were 35 and 19 mmol m${ }^{-2} \mathrm{yr}^{-1}$, respectively. Most of the nitrate was deposited under dry form, whilst ammonia was twice more found in wet deposition. Wet and dry fluxes of DIP, averaged over three years, were 0.11 and $0.64 \mathrm{mmol} \mathrm{m}^{-2} \mathrm{yr}^{-1}$, respectively. Atmospheric fluxes of DIN and DIP were compared with other photic zone nutrient input sources, physical and biological, i.e. winter convection, $\mathrm{N}_{2}$ fixation, and upward diffusion. Even if convection is by far the most important nutrient input for surface waters, atmospheric sources may be the second one, supplying more nutrients than diazotrophy and diffusion, particularly in conditions of water column stratification. 


\section{Introduction}

The Mediterranean Sea is a low nutrient, low chlorophyll, oligotrophic province (D'Ortenzio and Ribera d'Alcalà 2009; Pulido-Villena et al. 2010). The exchanges at the straits of Gibraltar and Bosphorus globally result in a significant net export of nutrients, approximately $10 \%$ for nitrogen (N) and phosphorus (P), and 50\% for silicon, approximately (Durrieu de Madron et al. 2011, and references therein). The net losses are hypothesized to be compensated by external sources at the climatological scale (Béthoux et al. 1998; Ribera d'Alcalà et al. 2003). An important role for atmospheric deposition might be a common characteristic of marine regions such as the Mediterranean Sea where the external physical forcing is strong, i.e., semi-enclosed or inland seas (Turley, 1999; Heimbürger et al., 2011). In particular, for the Mediterranean, owing to its reduced dimensions $\left(2.5110^{6} \mathrm{~km}^{2}\right)$, and to numerous and intense land-based emission sources of nutrients, open waters receive significant loads of nutrients. Indeed, atmospheric deposition is believed a significant source of nutrients to the marine surface layer (Guerzoni et al. 1999; Béthoux et al. 2002; Christodoulaki et al. 2013), and likely to fertilise oligotrophic Mediterranean waters, particularly in summer conditions of a stratified water column (Markaki et al. 2003; Bartoli et al. 2005; Lionello et al. 2006).

Atmospheric material has a characteristic $\mathrm{N}$ to $\mathrm{P}$ ratio. A preponderance of $\mathrm{N}$ relative to $\mathrm{P}$ in the atmospheric material is universally observed, with a factor sometimes $>1000$ in the north Atlantic (Baker et al. 2003; Bartoli et al. 2005; Krishnamurthy et al. 2010; Markaki et al. 2010). Because a high $\mathrm{N}: \mathrm{P}$ ratio is common, atmospheric nutrient inputs are generally deficient in $\mathrm{P}$ relative to phytoplankton requirements. In the Mediterranean, nutrient molar ratios are peculiar. Nitrate:phopshate values vary from 21 to 24, with mean value of 22 in the western basin (see review in Ribera d'Alcalà et al. 2003), and may locally reach values of about 100 at the bottom of the photic zone associated with the chlorophyll maximum (Diaz et al. 2001; Moutin and Raimbault 2002). Such values contrast with the typical Redfield ratio of 16 (Redfield 1934). One of the most frequently invoked reasons to explain this peculiarity is the strong influence of atmospheric deposition (Béthoux et al. 2002; Bartoli et al. 2005; Krom et al. 2010; Markaki et al. 2010).

In 2010, the MOOSE (Mediterranean Ocean Observing System for the Environment) network was set up to assess the spatial and temporal distribution of atmospheric inputs of nutrients over the French front of the northwestern Mediterranean basin, in relation to their fate and involvement in marine biogeochemical cycles. The present study was conducted within the MOOSE framework, and focuses on the Cap Ferrat Ligurian time-series station, with the double aim 1) to quantify the magnitude and temporal variability of partitioned atmospheric nutrient inputs, and 2) to evaluate the impact of such depositional fluxes on the overall nutrient budgets and stoichiometry of the northwestern Mediterranean. 


\section{Experimental}

\subsection{Sampling site}

The sampling station of Cap Ferrat, on the southeastern coast of France $\left(43^{\circ} 41^{\prime} \mathrm{N}, 7^{\circ} 19^{\prime} 30^{\prime}\right.$ ' E, altitude 130m; Fig. 1), is located on a peninsula surrounded by mountainous environment; it is sheltered from local sea-spray and direct continental sources with, however, a marked marine character. The Cap Ferrat sampling station has been previously defined (e.g., Chester et al. 1997) as a site overall affected by European anthropogenic background features upon which are superimposed episodic, pulsed Saharan dust events. The atmospheric material, generated by numerous and contrasted land-based emission sources, is generally transported by different air masses that exhibit both mineral and anthropogenic features. Previous work has shown that local contaminations were negligible at Cap Ferrat (e.g. Chester et al. 1997; Migon et al. 2008). This coastal site is representative of northern anthropogenic influences in the northwestern Mediterranean basin, and it presumably mirrors the atmospheric deposition over Ligurian marine areas, assuming that, at the scale of medium-range atmospheric transport, airborne material over the Ligurian region is fairly homogeneous (Sandroni and Migon 1997). As a general rule, the number of dry days in the Cap Ferrat region is much higher than that of wet days. During the present sampling period, 110, 72, and 99 rainy days occurred in 2010, 2011, and 2013, respectively (see http://www.meteofrance.com).

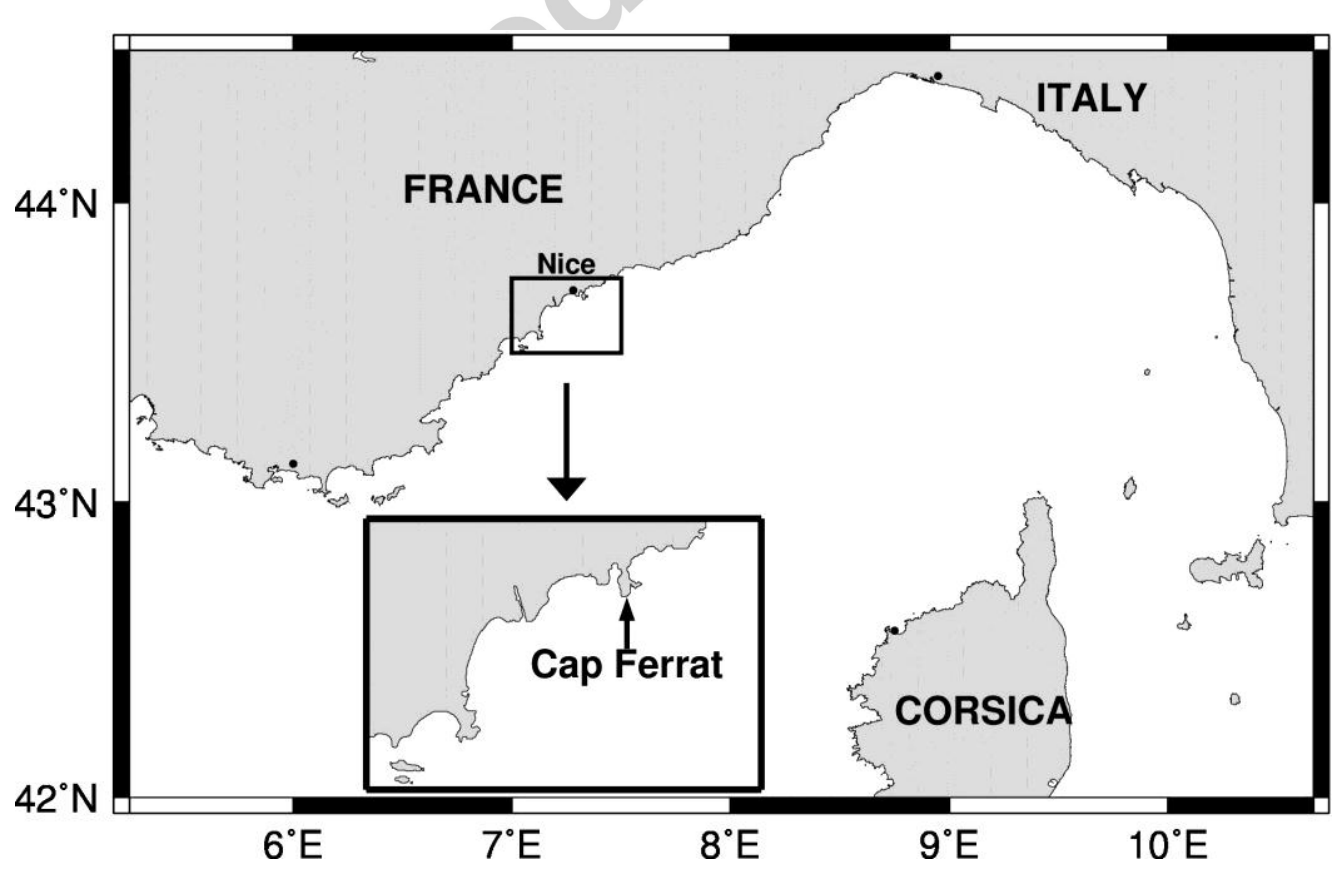

Fig. 1: Location of the time-series sampling site 


\section{ACCEPTED MANUSCRIPT}

\subsection{Sampling, sample preservation and analysis}

Atmospherically-deposited inorganic nutrients were sampled in 2010, 2011, and 2013. For technical reasons, year 2012 was not sampled. Samples were collected with a MTX ARS 1000 sampler (sampling surface area: $0.064 \mathrm{~m}^{2}$ ), which splits dry and wet deposition into two distinct polyethylene buckets, only when it rains, and not under the influence of fog or dew. Dry deposition was sampled every 15 days, whereas rainwater was systematically collected immediately after the end of the wet event, in order to limit the bacterial consumption of nutrients. Dry sample matter was retrieved by rinsing the sampling bottle with Milli-Q water. After filtration on GF/F filters (glass fiber, porosity $0.45 \mu \mathrm{m}$, diameter $47 \mathrm{~mm})$, samples were stored in freezer $\left(\mathrm{T}=-20^{\circ} \mathrm{C}\right)$ until analysis. Nitrate $\left(\mathrm{NO}_{3}{ }^{-}\right)$, nitrite $\left(\mathrm{NO}_{2}{ }^{-}\right)$, and phosphate $\left(\mathrm{PO}_{4}{ }^{3-}\right)$ ions were analysed by standard automated colourimetric system, using a Seal Analytical continuous flow AutoAnalyser III (AA3) according to the protocols of Raimbault et al. (1990) and Aminot and Kérouel (2004, 2007). Ammonium $\left(\mathrm{NH}_{4}{ }^{+}\right)$ ions were analysed by fluorescence according to Holmes et al. (1999) and Brad et al. (2007). Detection limits were $0.05,0.02,0.01$ and $0.02 \mu \mathrm{mol} \mathrm{\textrm {L } ^ { - 1 }}$ for nitrate, nitrite, ammonium and phosphate, respectively. Blanks (concentration values measured in Milli-Q water using the same analytical protocol, including filtration on GF/F filters) were $1.42 \pm 0.47 \mu \mathrm{M}\left(\mathrm{NO}_{3}{ }^{-}+\mathrm{NO}_{2}{ }^{-}\right), 1.37 \pm$ $1.05 \mu \mathrm{M}\left(\mathrm{NH}_{4}{ }^{+}\right)$, and $0.01 \pm 0.01 \mu \mathrm{M}\left(\mathrm{PO}_{4}{ }^{3-}\right)$, to be compared with the range of concentrations of Cap Ferrat samples within the present data set $\left(20-400 \mu \mathrm{M}\right.$ for the sum $\left(\mathrm{NO}_{3}{ }^{-}+\mathrm{NO}_{2}{ }^{-}\right), 0.5-80 \mu \mathrm{M}$ for $\mathrm{NH}_{4}{ }^{+}$and 0.5-10 $\mu \mathrm{M}$ for $\mathrm{PO}_{4}{ }^{3-}$, approximately. The quality of measurements has been checked by analysing certified Nutrient Standard Solutions (NSS) from OSIL (United Kingdom).

Soluble and insoluble fractions (from dry deposition samples), and dissolved and particulate fractions (from wet deposition samples) were discriminated by filtration. The soluble fraction of dry deposition samples was then added to the dissolved fraction of wet deposition samples to form the total pool that is viewed as a proxy of the atmospherically-deposited marine bio-available pool of inorganic nutrients, hereinafter referred to as 'dissolved inputs' of $\mathrm{N}$ and P (DIN and DIP, respectively; $\mathrm{DIN}=\mathrm{NO}_{3}{ }^{-}+\mathrm{NO}_{2}{ }^{-}+\mathrm{NH}_{4}{ }^{+}, \mathrm{DIP}=\mathrm{PO}_{4}{ }^{3-}$ ). In both wet and dry depositions, nitrite concentrations were not systematically measured individually. When nitrite was not measured, it occurred with nitrate, and when it was measured, its concentrations were always very low: they represented on average $0.4 \%$ of total dry deposition of soluble $\mathrm{N}$, and $1.8 \%$ in the wet deposition. It is thus assumed that the sum [nitrate + ammonium] globally accounts for the total input of DIN, and, in the following, nitrite will not be mentioned. The insoluble fraction of atmospheric nutrients was not analysed. Part of the insoluble fraction of dry deposition (as well as part of the particulate fraction of wet deposition) may dissolve in seawater, notably owing to zooplankton grazing and 
subsequent particle fractionation (Moore et al. 1984) and, thus, may release bio-available nitrate, ammonium and phosphate ions. However, without any additional data on this specific contribution, the solubility of the refractory remaining particulate fraction is arbitrarily presumed negligible and is not taken into account.

Despite their significant contribution to the pool of dissolved N and P (Kanakidou et al. 2012; Violaki et al. 2015), and, therefore, despite their potential assimilation by microorganisms (Karl and Yanagi 1997; Van Wambeke et al. 2002), the organic forms of $\mathrm{N}$ and $\mathrm{P}$ were not taken into account here.

\subsection{Modelling of the mixed layer depth}

The model used is a 3D free surface, generalised sigma vertical coordinate, described by Marsaleix et al. (2009, 2012). It has previously been used in the Mediterranean Sea to simulate convection in the open sea (Herrmann et al. 2008), as well as coastal dense water formation (Estournel 2005) and plankton ecosystem variability in the convection zone (Auger et al. 2014). We chose a horizontal resolution of $1 \mathrm{~km}$ to represent the scales related to the Rossby radius, of the order of 5-10 km. Forty vertical levels were used with closer spacing near the surface ( 15 levels in the first 100 metres in the centre of the convection zone characterised by depths of $\sim 2500 \mathrm{~m}$ ). The model was initialised and forced at its lateral boundaries with daily fields provided by the MERCATOR operational system based on the NEMO model. The configuration of this model was the PSY2V2R4 prototype at a resolution of $1 / 16^{\circ}$ over the Atlantic and the Mediterranean. The atmospheric forcing was calculated using the bulk formulae of Large and Yeager (2004). Meteorological parameters came from the ECMWF operational forecasts at $1 / 8^{\circ}$ horizontal resolution and 3 hours temporal resolution. These forecasts were derived from the daily analysis at 00.00 UTC. Values of the mixed layer depth (MLD) were obtained at the DYFAMED time-series station $\left(31^{\circ} 25^{\prime} \mathrm{N}, 71^{\circ} 52^{\prime} \mathrm{E}\right.$, central Ligurian Sea) at a one-day frequency over the $2010-2014$ period, using a $0.01 \mathrm{~kg} \mathrm{~m}^{-3}$ density criterion.

\section{Results and Discussion}

\subsection{Atmospheric fluxes}

Time-series of DIN and DIP depositions to the Cap Ferrat sampling site are depicted in Fig. 2a and Fig. 3a. DIN is composed of 66.1 and $77.4 \%$ nitrate + nitrite in wet and dry depositions, respectively, and of 33.9 and $22.6 \%$ ammonia in wet and dry depositions, respectively. Regarding wet deposition, the ratios are relatively close to findings from a previous study carried out at the same site ( 40\%; Migon et al. 1989). However, it should be noted that the nitrate-to-ammonium 
ratio exhibits very strong variability at the individual scale: the contribution of $\mathrm{NO}_{3}$ to total DIN varies from 15.2 to $99.9 \%$ in wet deposition, and from 0 to $99.5 \%$ in dry deposition.
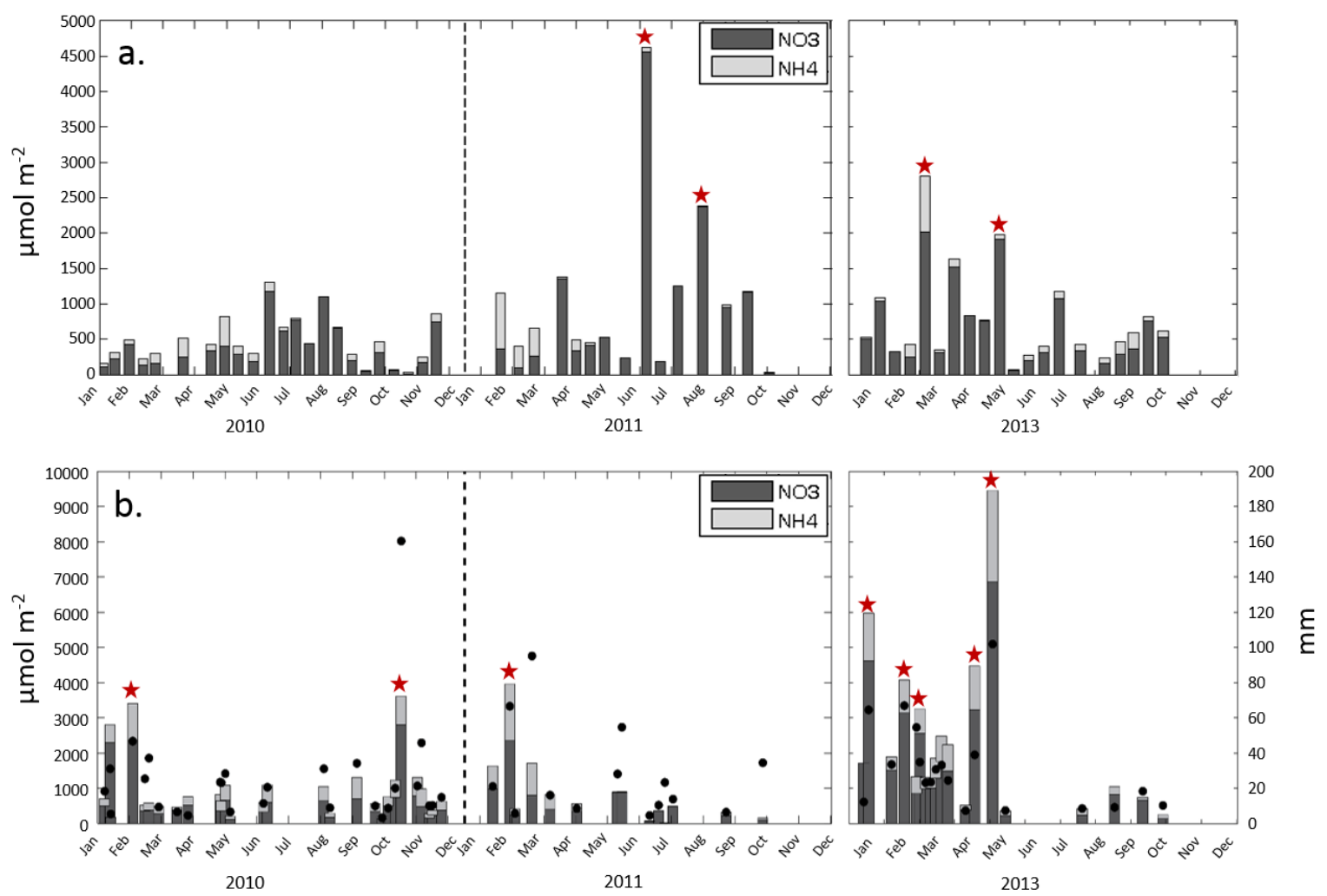

Fig. 2: DIN deposition in a. the dry phase and b. the wet phase. Black dots represent rainfall amount, and red stars point out extreme events (see text and Eq. 1) 

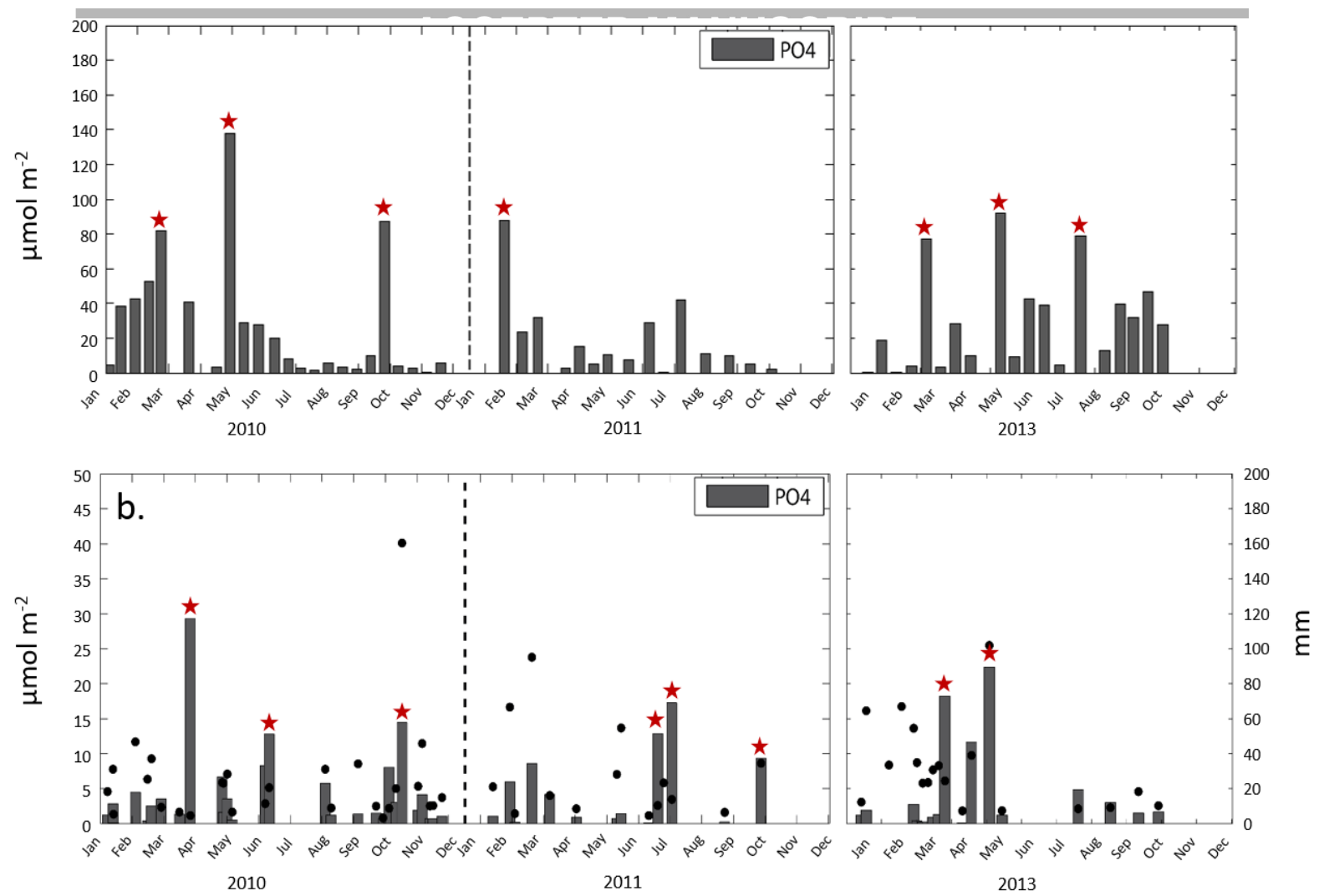

Fig. 3: DIP deposition in a. the dry phase and b. the wet phase. Black dots represent rainfall amount, and red stars point out extreme events (see text and Eq. 1)

Over a 15-day sampling interval, the dry deposition of DIN was generally lower than $1500 \mu \mathrm{mol} \mathrm{m}$ 2 (Fig. 2a), except during some restricted periods (e.g., June and August 2011, and March and May 2013). Year 2010 was less variable from event to event, with maximum values in summer (the driest season). In 2011 occurred the strongest event of the whole time-series: DIN deposition exceeded $4500 \mu \mathrm{mol} \mathrm{m} \mathrm{m}^{-2}$ over a 15-day sampling period during the second half of June. This event accounted for almost one third of the total DIN deposited by the dry mode in 2011. In 2013, the strongest dry deposition events were observed from March to May. No clear seasonal pattern can be observed in the DIN dry deposition (Fig. 4a), or, at least, the inter-annual variability masks the seasonal pattern. Similarly, a high variability is also observed in the dry deposition of DIP (Fig. 3a). Maximum events of DIP dry deposition were observed in May and October 2010, January 2011 and May 2013. With regard to DIN wet deposition, no seasonal pattern could be clearly defined (Fig. 4b). As a probable consequence of the variety of incoming air masses that affect the Cap Ferrat sampling site, only the deposition of elements and compounds of marked character (anthropogenic or natural) exhibits a clear seasonality: According to seasonal changes in land-based emission sources, and to prevailing airflow rates, anthropogenic events occur mostly at the end of summer/beginning of autumn, and in winter, with maxima generally in September/October and the 
end of March (see discussion in Migon et al. 2008). Saharan dust episodes generally occur during spring and summer in the northwestern Mediterranean region (Moulin et al. 1997).
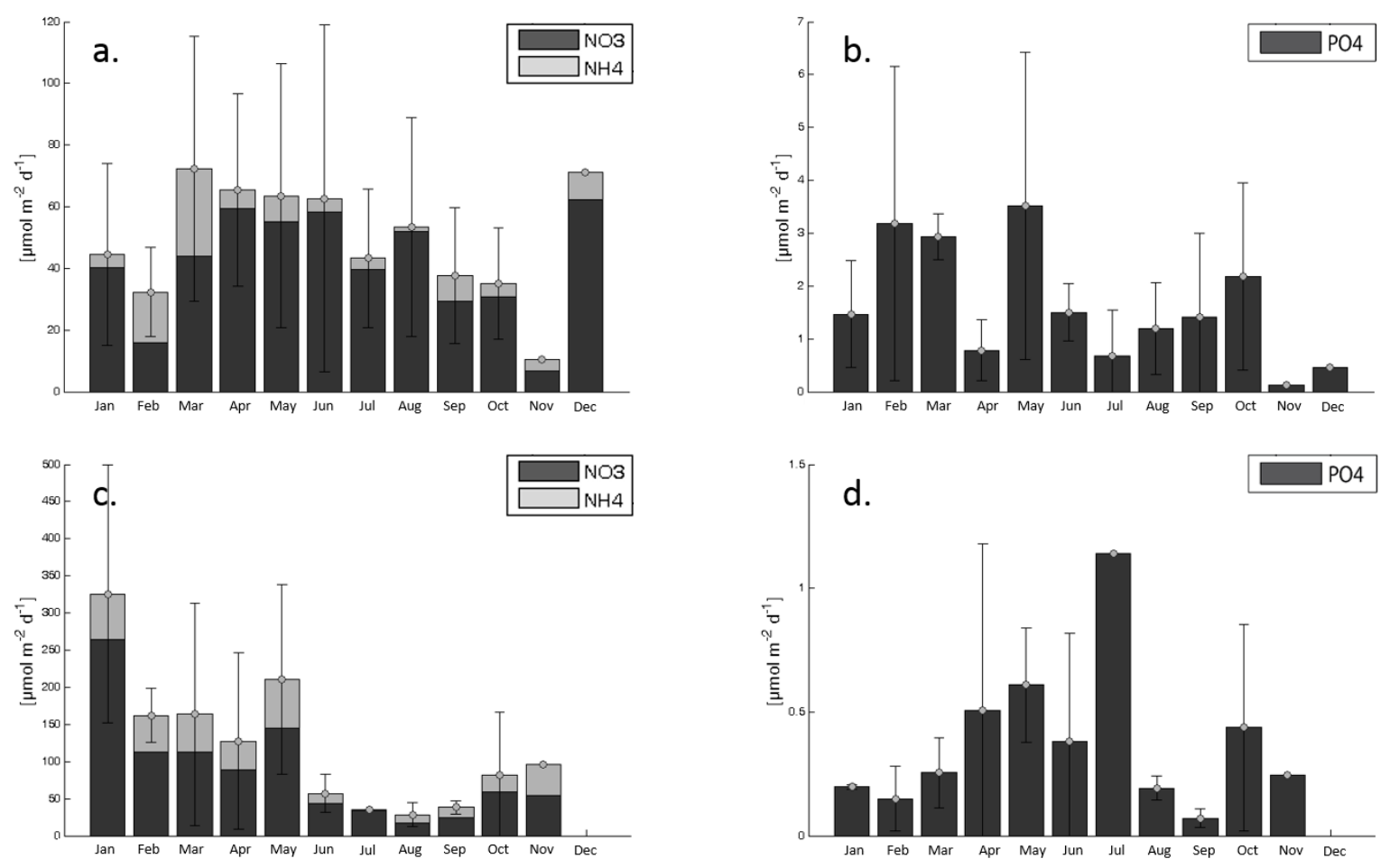

Fig. 4: Monthly bar plot of a. dry deposition of DIN; b. dry deposition of DIP; c. wet deposition of DIN; d. wet deposition of DIP. Error bars are 2 times the standard deviation length

Rainfall amount is a key parameter to constrain DIN and DIP in wet deposition. Strong DIN deposition events are clearly associated with large amounts of rain (e.g., October 2010, February 2011, January 2013 and May 2013; Fig. 2b). Thus, a significant relationship exists between DIN deposition in the wet phase and rainfall amount (Spearman's rank correlation coefficient $=0.76$ ), although this relationship is not linear (Fig. 5). DIN in wet deposition exhibits a conspicuous seasonal pattern, despite strong inter-annual variability. Maximum values occur during the wet season, and minimum values in summer during dry season (from June to September) (Fig. 4). LoÿePilot et al. (1990) have observed in Corsica that the annual flux of DIN slightly increases with annual rainfall amount. Such a pattern has been also observed in the eastern Mediterranean (Violaki et al. 2010). As well, Krom et al. (2004) have partly explained the observed difference (by a factor of slightly more than two) between inorganic $\mathrm{N}$ fluxes in eastern and northwestern basins by higher annual rainfall in the northwestern basin. The strong co-variability observed between DIN fluxes and rainfall amount may mirror the prevalence of fine particles, which is characteristic of overall anthropogenic origin. Indeed, atmospheric DIN is basically derived from anthropogenic combustion or agricultural sources throughout the world (Duce et al. 2008). Combustion is probably a more 
significant contribution in densely urbanised/Northern Ligurian region, where high DIN contribution has been already attributed to strong anthropogenic influence (Sandroni et al. 2007). Fig. 5 also suggests that DIP content in wet deposition increases with rainfall amount. However, the correlation is weaker than for the case of DIN (Spearman's rank correlation coefficient $=0.29$ ), and the relationship appears more complex. The atmospheric deposition of $\mathrm{P}$ is chiefly driven by the dry mode. On average, the dry deposition of soluble phosphate accounts for $85 \%$ of the total input of DIP, ranging between 78.4 (2011) and 89.9\% (2013). This presumably mirrors coarser particles, compared with DIN. Indeed, DIP particles have dual origin: both anthropogenic and Saharan dust events contribute to DIN deposition at global scale (Mahowald et al. 2008). At regional scale, previous observations at the same sampling station and at Capo Cavallo (northwestern coast of Corsica) have shown the importance of the two emission sources (Bergametti et al. 1992; Bartoli et al. 2005). Regarding the impact of regional sources of anthropogenic DIP on Cap Ferrat samples, Migon et al. (2001) previously pointed out the significance of urban incinerators. At yearly scale, the significant difference between DIN dry/wet and DIP dry/wet ratios confirms that the atmospheric deposition of $\mathrm{N}$ is mostly associated with the wet mode (mean DIN dry/wet ratio $<1$ ), contrarily to DIP (mean DIP dry/wet ratio > 1).
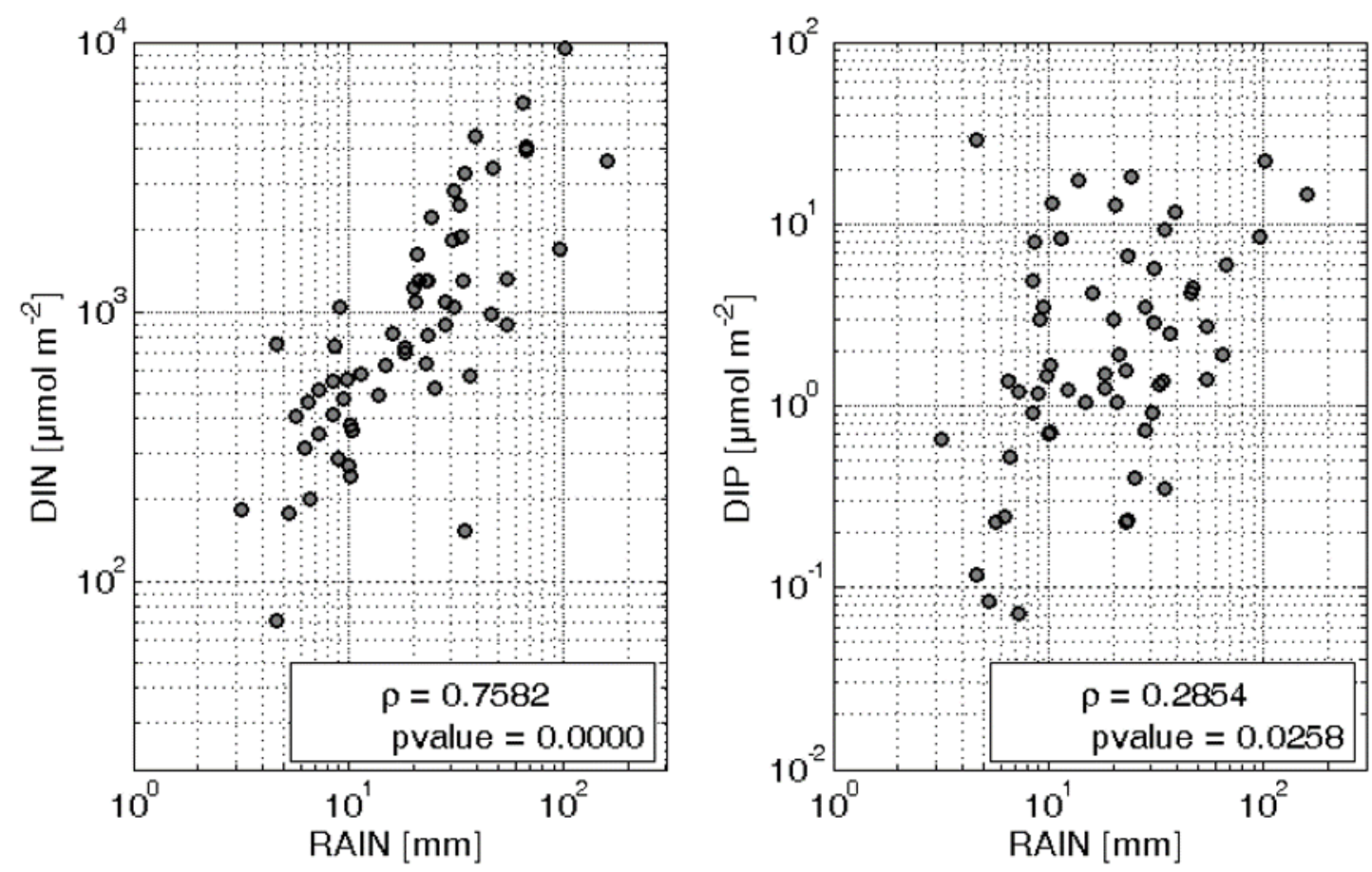

Fig. 5: Scatter plot of rainfall amount versus DIN and DIP wet deposition

The strong inter-annual variability previously shown (Fig. 2 and 3) suggests that DIN and DIP deposition is driven by a few events of large magnitude. These extreme events were characterised according to the criteria of Hampel et al. (2011), as the values that exceed: 
where $\operatorname{med}(\mathrm{x})$ is the median value of the considered time-series of $\mathrm{x}$ values (i.e. DIN and DIP in dry and wet deposition), and MAD is the median absolute deviation calculated as follows: MAD = $\operatorname{mdn}(|x-\operatorname{mdn}(x)|)$. In wet deposition, extreme events represent only 13.5 and $15.5 \%$ of the total number of events for DIN and DIP, respectively, but they account for 47 and $57 \%$ of the total deposition of DIN and DIP, respectively. The proportion of extreme events is less important in dry deposition (6 and 12\% for DIN and DIP, respectively), with a contribution of 27 and $44 \%$ of the total input for DIN and DIP, respectively. This confirms the key role of episodic pulses affecting Mediterranean surface waters, in agreement with findings of Guieu et al. (2014). Interestingly, extreme DIP inputs rarely coincided with high DIN inputs for both dry and wet deposition.

\subsection{Nutrient budgets}

Mean annual atmospheric fluxes of nutrients to the Cap Ferrat sampling site were calculated, and results are reported in Table 1. Annual fluxes were computed as the sum of deposition events divided by the number of measurement days, multiplied by 365 , in order to avoid biases due to missing data by computing the straightforward sum. The mean daily flux is considered during periods of missing data, instead of considering that no data correspond to nil flux. The annual atmospheric fluxes of DIN and DIP, averaged over the 3 years of measurement, are $54 \pm 16 \mathrm{mmol}$ $\mathrm{m}^{-2} \mathrm{yr}^{-1}$ and $0.75 \pm 0.22 \mathrm{mmol} \mathrm{m}^{-2} \mathrm{yr}^{-1}$, respectively. These fluxes are roughly within the range of previous measurement at Cap Ferrat, although the wet deposition of DIN was $47.8 \mathrm{mmol} \mathrm{DIN} \mathrm{m}^{-2}$, on average, during wetter years 1986 and 1987 (Migon et al. 1989), and the dry deposition of DIN was 40 in 2004 (Sandroni et al. 2007). The total deposition of DIP was higher at Capo Cavallo (slightly less than $1.3 \mathrm{mmol}^{\mathrm{DIP} \mathrm{m}^{-2}}$ between April 1985 and March 1988 (Bergametti et al. 1992), presumably because the Corsican site is more affected by desert dust deposition events.

\begin{tabular}{|l|l|l|l|l|l|l|l|l|l|}
\hline & \multicolumn{3}{|c|}{ DIN } & \multicolumn{3}{c|}{ DIP } & \multicolumn{3}{c|}{ N:P } \\
\hline & $\begin{array}{c}\text { Atmospheric } \\
\text { input }\end{array}$ & $\begin{array}{c}\text { Winter } \\
\text { mixing }\end{array}$ & \multicolumn{2}{c|}{$\begin{array}{c}\text { Atmospheric } \\
\text { input }\end{array}$} & $\begin{array}{c}\text { Winter } \\
\text { mixing }\end{array}$ & $\begin{array}{c}\text { Atmospheric } \\
\text { input }\end{array}$ & $\begin{array}{c}\text { Winter } \\
\text { mixing }\end{array}$ \\
\hline & Wet & Dry & & Wet & Dry & & Wet & Dry & \\
\hline 2010 & 33 & 14 & $3.210^{3}$ & 0.15 & 0.76 & 140 & 218 & 18 & 23 \\
\hline 2011 & 20 & 23 & $1.510^{3}$ & 0.10 & 0.40 & 60 & 204 & 56 & 26 \\
\hline
\end{tabular}




\begin{tabular}{|l|l|l|l|l|l|l|l|l|l|}
\hline 2013 & 52 & 21 & $0.210^{3 \mathrm{AC}}$ & 0.09 & 0.75 & 8 CR IPT & 582 & 28 & 33 \\
\hline mean & 35 & 19 & $1.710^{3}$ & 0.11 & 0.64 & 69 & 335 & 34 & 24 \\
\hline
\end{tabular}

Table 1: Mean annual atmospheric fluxes of DIN and DIP (expressed in mmol $\mathrm{m}^{-2} \mathrm{yr}^{-1}$ ) and N/P molar ratios. Mean molar ratios are computed as ratios of annual deposition of DIN to annual deposition of DIP (and not as the mean of $\mathrm{N} / \mathrm{P}$ ratios of every event). This allows a better estimation of the relative impacts of $\mathrm{N}$ and $\mathrm{P}$ atmospheric loads, and of winter mixing, on overall stocks, instead of simply giving information on mean N/P ratios.

In order to evaluate the importance of atmospheric deposition as a source of nutrients to the Ligurian Sea, we compared it with other physical and biological processes likely to bring nutrients to the photic layer. Such processes are chiefly convection, $\mathrm{N}_{2}$ fixation, and diffusion. Convection is probably the most important way to replenish the photic layer in regions where external conditions (temperature, wind, stress, precipitation rate, etc.) permit the downwelling of surface waters (Marty et al. 2002), and the northwestern Mediterranean is an area of deep water formation, actually (D'Ortenzio et al. 2005). However, very few quantitative studies have dealt with the contribution of winter mixing on nutrient supply to the surface layer, and most of them are related to the eastern Mediterranean (Yılmaz and Tugrul 1998; Gačić et al. 2002; Santinelli et al. 2012). To our knowledge, only one addresses the issue in the Liguro-provençal basin (Severin et al. 2014). Indeed, events of MLD deepening are processes of short duration (few days). Thus, their assessment from standard ship measurements is very difficult, and often questionable with the available resolution of the data (even considering a monthly sampling; Pasqueron de Fommervault et al. 2015). Although it is not possible to determine accurately the contribution of winter mixing directly from in situ measurements, we estimated the annual flux of nutrients (nitrate and phosphate) by coupling in situ nutrient measurements and modelled MLD values at DYFAMED over the 2010-2014 period (Fig. $6)$.

Climatological profiles of nitrate and phosphate concentrations in autumn were considered and supposed representative of the vertical nutrient distribution before the mixing period (data from Pasqueron de Fommervault et al. 2015, reported in Table 2). Thus, we estimated the convective inputs of nutrients by considering the impact of each MLD deepening event (defined as the time interval during which the MLD is always deeper than the photic layer) on climatological profiles, assuming homogeneous concentrations within the mixed layer (Equation 1).

$\mathrm{F}_{\mathrm{NUT}}=\int_{\mathrm{Zeu}}^{\mathrm{MLD}} \mathrm{NUT}(\mathrm{z}) \cdot \mathrm{dz} \cdot \frac{\mathrm{Zeu}}{\mathrm{MLD}}$

where $\mathrm{F}_{\mathrm{NUT}}$ corresponds to the nutrient flux to the photic layer $\left(\mathrm{Z}_{\mathrm{eu}}\right)$ during a MLD deepening event. $Z_{\mathrm{eu}}$ varies from 32 to $46 \mathrm{~m}$ at DYFAMED in winter (Organelli et al. 2014), and is fixed at 
40m. NUT is the considered nutrient concentration (nitrate or phosphate only, because of insufficient available ammonium data). The total quantity of nutrients brought to the photic layer then corresponds to the sum of $\mathrm{F}_{\mathrm{NUT}}$ values, and supposedly sustains winter and spring primary production.

\begin{tabular}{|l|l|l|}
\hline $\begin{array}{l}\text { Reference } \\
\text { depth }\end{array}$ & $\begin{array}{l}\text { Nitrate } \\
{[\mu \mathrm{M}]}\end{array}$ & $\begin{array}{l}\text { Phosphate } \\
{[\mu \mathrm{M}]}\end{array}$ \\
\hline 0 & 0.19 & 0.03 \\
\hline 10 & 0.25 & 0.03 \\
\hline 30 & 0.92 & 0.05 \\
\hline 50 & 2.68 & 0.09 \\
\hline 70 & 4.73 & 0.17 \\
\hline 90 & 6.41 & 0.23 \\
\hline 110 & 6.93 & 0.28 \\
\hline 150 & 7.29 & 0.31 \\
\hline 200 & 7.46 & 0.34 \\
\hline 300 & 7.76 & 0.36 \\
\hline 400 & 7.96 & 0.37 \\
\hline 500 & 8.06 & 0.37 \\
\hline 600 & 8.02 & 0.37 \\
\hline 800 & 7.88 & 0.36 \\
\hline
\end{tabular}




\begin{tabular}{|l|l|l|}
\hline 1000 & 7.78 & 0.37 ARIP \\
\hline 1300 & 7.75 & 0.38 \\
\hline 1800 & 7.68 & 0.37 \\
\hline
\end{tabular}

Table 2: Autumn mean vertical nitrate and phosphate concentrations at the DYFAMED time-series station calculated over the period 1991-2001.

Time-series of $\mathrm{F}_{\mathrm{NUT}}$ are shown in Fig. 6. The nitrate supply to the photic layer was estimated as 3.2, 1.5 and $0.210^{3} \mathrm{mmol} \mathrm{N} \mathrm{m}^{-2} \mathrm{yr}^{-1}$ during winters 2010/2011, 2012/2013 and 2013/2014. Similarly, the phosphate supply was around 140, 60 and $8 \mathrm{mmol} \mathrm{P} \mathrm{m}^{-2} \mathrm{yr}^{-1}$ in winters 2010/2011, 2012/2013 and 2013/2014. The large interannual variability of nutrient refueling is mostly related to that of MLD. Indeed, the modelled MLD reached more than 2000m during winter 2010/2011, and was around 600m during winter 2012/2013, and never exceeded 100m during winter 2013-2014 (Fig. 6). In addition, the convective period lasted almost four months in winter 2010/2011 (from late December to mid-March), but only 2 months in winters 2011/2012 and 2013/2014. Over the three considered years, it represents a mean annual flux of $1.710^{3} \mathrm{mmol} \mathrm{N} \mathrm{m}^{-2} \mathrm{yr}^{-1}$ and $69 \mathrm{mmol} \mathrm{P} \mathrm{m}^{-2} \mathrm{yr}^{-}$ ${ }^{1}$ (Table 1). 

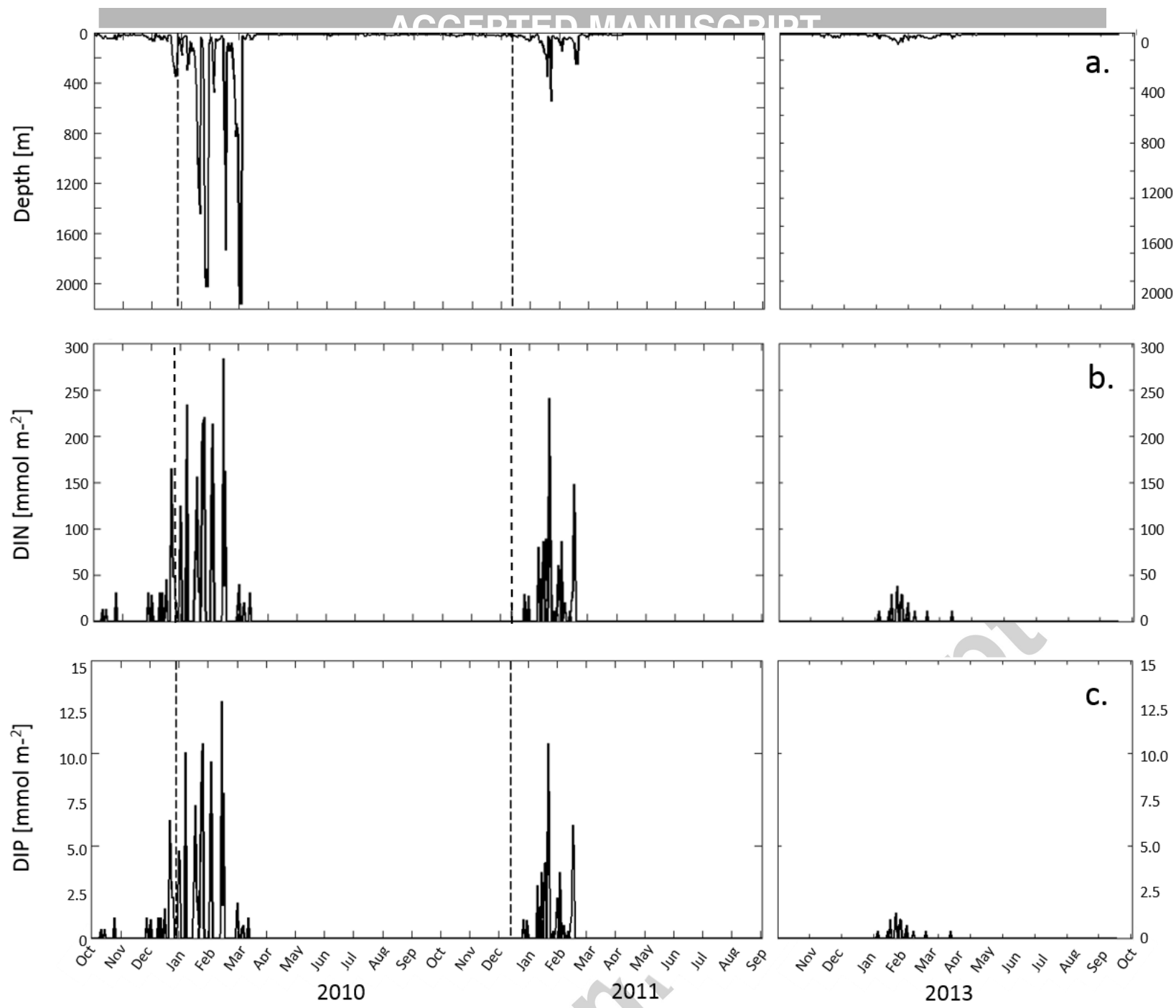

Figure 6: Time-series of (a) the modelled MLD at the DYFAMED station, (b) convective input of nitrate, (c) convective input of phosphate.

Diffusion from deep layers and $\mathrm{N}_{2}$ fixation were not directly estimated in this paper, and results from previous studies carried out in the area were used. During the MINOS cruise (from May 21 to June 29, 1996), Moutin and Raimbault (2002) estimated $\mathrm{PO}_{4}$ and $\mathrm{NO}_{3}$ fluxes at 20 stations, including one in the northwestern Mediterranean sea, using slope of nutriclines and a turbulent kinetic energy dissipation rate of $710^{-10} \mathrm{~W} \mathrm{~kg}^{-1}$. From Fick's law (Okubo 1971), $\mathrm{PO}_{4}$ and $\mathrm{NO}_{3}$ fluxes were estimated in the order of 0.9 and $17 \mu \mathrm{mol} \mathrm{m}^{-2} \mathrm{~d}^{-1}$, respectively (station 1; Moutin and Raimbault 2002). Assuming that this daily rate can be extrapolated throughout the year, mean annual fluxes of $\mathrm{PO}_{4}$ and $\mathrm{NO}_{3}$ are around 6.2 and $0.3 \mathrm{mmol} \mathrm{m} \mathrm{yr}^{-1}$, respectively. Dinitrogen fixation (diazotrophy) is also a possible source of new $\mathrm{N}$ to surface waters. The occurrence of this process has been already postulated and evidenced in the Mediterranean Sea (Sachs and Repeta 1999; Pantoja et al. 2002), including the Ligurian area (Garcia et al. 2006; Sandroni et al. 2007). The significance of diazotrophy in the Mediterranean Sea is still controversial and largely unknown, 
however. In the northwestern Mediterranean, diazotrophy was estimated varying from 10 to $76 \mu \mathrm{mol}$ $\mathrm{N} \mathrm{m}^{-2} \mathrm{~d}^{-1}$ in June-July (Dyhrman et al. 2011). In central Ligurian Sea, the yearly integrated $\mathrm{N}_{2}$ fixation was $77 \mu \mathrm{mol} \mathrm{N} \mathrm{m} \mathrm{d}^{-1}$ over the year 2004 (i.e. $28 \mathrm{mmol} \mathrm{N} \mathrm{m}^{-2} \mathrm{yr}^{-1}$ ), with a minimum of 22 $\mu \mathrm{mol} \mathrm{N} \mathrm{m} \mathrm{d}^{-1}$ in October and a maximum of $245 \mu \mathrm{mol} \mathrm{N} \mathrm{m} \mathrm{d}^{-1}$ in August (Sandroni et al. 2007). The significance of the above estimated fluxes should be moderated because of important, and difficult to estimate, errors. In particular, mean values of nutrient fluxes related to winter mixing mask a large disparity due to interannual variability in MLD dynamics. In addition, calculated MLD values apply to a fixed point (here, DYFAMED) and, therefore, do not take into account spatial variability. As well, there is great uncertainty in the computation of the diffusive flux, due to large variations in the estimations of $\mathrm{K}_{\mathrm{z}}$ (Copin-Montégut 2000; Cuypers et al. 2012; Moutin and Raimbault 2002).

\begin{tabular}{|c|c|c|c|c|c|c|c|}
\hline & \multicolumn{4}{|c|}{ DIN } & \multicolumn{3}{c|}{ DIP } \\
\hline & $\begin{array}{c}\text { Atmospheric } \\
\text { inputs }\end{array}$ & $\begin{array}{c}\text { Winter } \\
\text { mixing }\end{array}$ & Diazotrophy & Diffusion & $\begin{array}{c}\text { Atmospheric } \\
\text { inputs }\end{array}$ & $\begin{array}{c}\text { Winter } \\
\text { mixing }\end{array}$ & Diffusion \\
\hline 2010 & 1.4 & 97.5 & 0.9 & 0.2 & 0.6 & 99.2 & 0.2 \\
\hline 2011 & 2.7 & 95.1 & 1.8 & 0.4 & 0.8 & 98.7 & 0.5 \\
\hline 2013 & 23.8 & 65.0 & 9.1 & 2.1 & 9.2 & 87.5 & 3.3 \\
\hline
\end{tabular}

Table 3: Comparison of annual fluxes of DIN and DIP to the surface layer considering the different sources (mixing, diffusion, atmospheric inputs and $\mathrm{N}_{2}$ fixation), all expressed in percentage of the total nutrient input.

Integrated over the year, both diazotrophy (which is generally considered of low significance in the Mediterranean Sea; Sandroni et al. 2007; Ibello et al. 2010; Krom et al. 2010; Yogev et al. 2011) and diffusion contribute little to the nutrient supply, compared to atmospheric input. Winter mixing is clearly the main source of new nutrients to the photic layer: it represents 65 to more than $97 \%$ of the annual DIN supply, and 87.5 to $99.2 \%$ for the annual DIP supply over the 3 years considered (Table 3). Interannual variability is considerable. Atmospheric inputs of DIN accounted for less than $3 \%$ in 2010 and 2011, but contributed almost 24\% in 2013, owing to low convective input (Fig. 6 and Table 1) and high atmospheric fluxes. The contribution of the atmosphere to the total DIP input is lower, 0.6 and $0.8 \%$ in 2010 and 2011, respectively, and $9.2 \%$ in 2013 . Nevertheless, atmospheric input is a continuous source of new nutrients (Fig. 4), whereas the input from mixing occurs almost always in winter, when MLD is deep enough to reach the deep nutrient reservoir. This occurs between November and March in the MLD time-series (Fig. 6), otherwise the MLD is shallow, and the depleted surface layer isolated from subjacent layers. In period of stratification (April-October), atmospheric input may be a significant source of new $\mathrm{N}\left(134 \mu \mathrm{mol} \mathrm{N} \mathrm{m} \mathrm{d}^{-1}\right.$ 
considering wet and dry deposition) and new $\mathrm{P}\left(\sim 2 \mu \mathrm{mol} \mathrm{P} \mathrm{m}^{-2} \mathrm{~d}^{-1}\right)$. Compared to diffusion flux (Moutin and Raimbault 2002), and diazotrophy from April to October (Sandroni et al. 2007), the atmospheric contribution to total DIN and DIP inputs accounts, on average, for slightly more than $60 \%$ and $70 \%$, respectively.

\subsection{Potential impact on N:P marine stock and biological productivity}

Taking into account the diversity and intensity of emission sources along the Mediterranean shores (natural Saharan dust vs many anthropogenic sources), it is expected that the variability of nutrient atmospheric deposition is high, and, therefore, the atmospheric N:P ratio is highly variable as well. At Cap Ferrat, the total annual $\mathrm{N}$ deposition is, on average, 335 times higher than that of $\mathrm{P}$ in the wet fraction, and 34 times in the dry fraction (Table 1). It ranges from 16 to 9000 in rainwater, with a median value of 400, and from 3 to more than 2000 in the dry material, with a median value of 32. There is a common consensus to partly explain the high $\mathrm{N}: \mathrm{P}$ values observed in Mediterranean waters, compared with values predicted by the Redfield model, by this atmospheric N and P imbalance (e.g., Herut et al. 1999; Ribera d'Alcalà et al. 2003). Riverine inputs may also be an important source for nutrient stocks in the Mediterranean Sea, too, and may potentially support high $\mathrm{N}: \mathrm{P}$ ratio (Ludwig et al. 2009). However, the direct impact of riverine discharge is believed particularly low in the Ligurian Sea because, on the one hand, the Northern Current presumably isolates it from the Rhône river plume and from lateral inputs (Niewadomska et al. 2008) and, on the other hand, riverine inputs are particularly poor in this region (Migon 1993).

One can also note that the average convective nutrient input exhibits a N:P molar ratio 24.2 (Table 1 ), which is much more than the usual Redfield value $(\mathrm{N}: \mathrm{P}=16)$. On the one hand, it is not surprising since the convective nutrient ratio is expected to reflect the nutrient ratio at depth, which is clearly non-Redfield in this area. Thus, in the present data set, when the modelled MLD is deeper than $\sim 200 \mathrm{~m}$, convective nutrient inputs exhibit N:P ratios around 21-22, close to the value at depth (Pasqueron de Fommervault et al. 2015), which increases when the MLD is shallow (i.e. < 200m). This mirrors a shallower nitracline relative to phosphacline, and, therefore, DIN inputs relatively higher than DIP inputs for shallow MLD. In other words, the depth reached by the MLD influences the nutrient stoichiometry, as already observed by Severin et al. (2014) in the Golf of Lion.

Atmospheric deposition and convection, together with diazotrophy, lead to high N:P ratio in the surface layer (see Table 1), and suggest that fluxes of nutrients entering sea surface are always Nenriched relative to $\mathrm{P}$ in the northwestern Mediterranean, in terms of biological needs according to the Redfield model. This is in agreement with most recent findings (i.e. control of phytoplankton productivity by $\mathrm{P}$ availability during the greatest part of the year) in the Ligurian Sea (Pasqueron de Fommervault et al. 2015). The Redfield model $(\Delta \mathrm{P} / \Delta \mathrm{N} / \Delta \mathrm{C}=1 / 16 / 106)$ may be used to 
approximately compute the theoretical new production (NP) triggered by DIP loads. Summing yearly atmospheric inputs, vertical diffusion and winter mixing, the annual NP ranges from 179.6 $\mathrm{gC} \mathrm{m}^{-2} \mathrm{yr}^{-1}$ in 2011 and $11 \mathrm{gC} \mathrm{m}^{-2} \mathrm{yr}^{-1}$ in 2013 with an intermediate value of $77 \mathrm{gC} \mathrm{m}^{-2} \mathrm{yr}^{-1}$ in 2012. The $\mathrm{Z}_{\mathrm{eu}}$ deepening in late spring also brings nutrients to the productive layer, and contributes to NP. Integrating DIP concentrations from winter $\mathrm{Z}_{\mathrm{eu}}(\sim 40 \mathrm{~m})$ to summer $\mathrm{Z}_{\mathrm{eu}}(\sim 80 \mathrm{~m}$; Organelli et al. 2014) gives a NP around 6-12 $\mathrm{gC} \mathrm{m}^{-2} \mathrm{yr}^{-1}$.

The above evaluations are to be compared with annual NP measurements and estimations at DYFAMED: 42 (Marty and Chiaverini 2002) to 52 (Béthoux 1989) and $59 \mathrm{gC} \mathrm{m}^{-2} \mathrm{yr}^{-1}$ (Sandroni et al. 2007). This highlights the wide interannual variability of primary production in the Ligurian Sea region (Bosc et al. 2004), presumably caused by the interannual variability of MLD. This variability does not significantly change our results and conclusions, since the winter mixing remains by far the largest source of nutrients to the photic layer. Nonetheless, atmospheric deposition is a significant source of nutrients to northwestern Mediterranean waters, in particular in summer conditions of stratification and surface water depletion. Interestingly, sediment trap studies at DYFAMED site show that atmospheric fluxes are generally not associated with significant export fluxes (Migon et al. 2002; Heimbürger et al. 2013, 2014). This suggests that the fertilising impact of atmospheric deposition on phytoplankton production remains poorly understood (Guieu et al. 2014). More generally, Volpe et al. (2009) have stated that dust deposition has no significant impact on phytoplankton dynamics in the Mediterranean Sea. It is therefore difficult to go beyond terms of nutrient stocks and limitation.

\section{Conclusions}

The present work aimed at improving knowledge on the composition and magnitude of DIN and DIP atmospheric deposition, and its impact on northwestern Mediterranean waters. Results confirm the major role of the atmospheric component in controlling standing stocks and, therefore, chemical limitation of primary productivity. Atmospheric input, while considerably lower than input from vertical mixing, is likely more important than diazotrophy (for the case of $\mathrm{N}$ ) and upward diffusion at yearly scale. In addition, the atmospheric input is continuous throughout the year, and its impact may be crucial during conditions of water column stratification, when the surface layer is nutrientdepleted and isolated from deeper layers, without mixing process (Bartoli et al. 2005). However, the comparison of atmospheric deposition with other significant sources of nutrients remains poorly documented, mainly because of marine under-sampling. Indeed, marine sampling campaigns in central Ligurian Sea are monthly (DYFAMED site; see, e.g., Marty et al. 2002; Pasqueron de Fommervault et al. 2015). This periodicity renders somewhat questionable the comparison between 
respective nutrient loads of atmospheric deposition and, e.g., winter convection, because the latter requires a high-frequency sampling to be well described. The estimation of nitrate concentrations from moorings and profiling floats has been already achieved in the past (e.g., Johnson et al. 2006, 2013). A nitrate sensor will be used at the DYFAMED mooring in the next months, while a network of floats equipped with nitrate sensors is already operational in the northwestern Mediterranean (NAOS project). In addition, the present study only considers inorganic forms of nutrients. Organic forms of nutrients are an alternative nutritive source for microorganisms, particularly in conditions of oligotrophy, because once surface waters are nutrient-depleted, most of remaining nutrient species are organic, a priori more difficult (when possible) to fix. It has long been known that when concentrations of soluble inorganic forms of nutrients are insufficient to meet the potential demands of microorganisms, organic forms can play a major role: either they are spontaneously hydrolysed in sea water, and they can be assimilated as easily as so-called reactive forms, or marine microorganisms (heterotrophic bacteria and picophytoplankton) are able to assimilate them via enzymatic cleavage (e.g., Johannes 1964; Van Wambeke et al. 2002). In oligotrophic systems, some organic forms of nutrients such as phosphonates can also be assimilated by species such as ubiquitous Trichodesmium in case of severe P-depletion and, thus, impact on the bio-availability of nutritive substances (Dyhrman et al. 2006). The quantification and characterisation of the bioassimilable fraction of the pool of organic nutrients requires specific studies (the pool of nonreactive dissolved nutrients is composed of a wide variety of species hydrolysable at various degrees). High-frequency sampling and study of non-reactive forms of nutrients are certainly the two major research directions directions to pursue in resolving nutrient dynamics and availability in the Mediterranean Sea.

\section{Aknowledgements}

The authors aknowledge a grant provided by the ACRI-ST company and the French National Association for Research and Technology (ANRT). This work was partly supported by the French MOOSE network (funded by ALLENVI, INSU, Eurosites), and by the French 'Equipement d'avenir' NAOS project (ANR J11R107-F). The authors are also grateful to John Dolan for language corrections and to two anonymous reviewers for their helpful comments.

\section{References}

[1] Aminot, A., Kérouel, R., 2004. Hydrologie des écosystèmes marins. Paramètres et analyses, Ed. Ifremer, $336 \mathrm{pp}$. 
[2] Aminot, A., Kérouel, R., 2007. Dosage automatique des nutriments dans les eaux marines : méthodes en flux continu. MEDD and Quae Publishers, France, 188 pp., ISBN $10275920023 X$.

[3] Auger, P.A., Ulses, C., Estournel, C., Stemmann, L., Somot, S., Diaz, F., 2014. Interannual control of plankton communities by deep winter mixing and prey/predator interactions in the NW Mediterranean: Results from a 30-year 3D modeling study. Progr. Oceanogr. 124, 12-27.

[4] Baker, A.R., Kelly, S.D., Biswas, K.F., Witt, M., Jickells, T.D., 2003. Atmospheric deposition of nutrients to the Atlantic Ocean. Geophys. Res. Lett. 30, 24, 2296, doi:10.1029/2003GRL018518.

[5] Bartoli, G., Migon, C., Losno, R., 2005. Atmospheric input of dissolved inorganic phosphorus and silicon to the coastal northwestern Mediterranean Sea: fluxes, variability and possible impact on phytoplankton dynamics. Deep-Sea Res. I 52, 2005-2016, doi:10.1016/j.dsr.2005.06.006.

[6] Bergametti, G., Remoudaki, E., Losno, R., Steiner, E., Buat-Ménard, P., 1992. Source, transport and deposition of atmospheric phosphorus over the Northwestern Mediterranean. J. Atmos. Chem. $14,501-513$.

[7] Béthoux J.P., 1989. Oxygen consumption, new production, vertical advection and environmental evolution in the Mediterranean Sea. Deep-Sea Res. 36, 769-781.

[8] Béthoux, J.P., Morin, P., Chaumery, C., Connan, O., Gentili, B., Ruiz-Pino, D., 1998. Nutrients in the Mediterranean Sea, mass balance and statistical analysis of concentrations with respect to environmental change. Mar. Chem. 63, 155-169.

[9] Béthoux, J.P., Morin, P., Ruiz-Pino, D., 2002. Temporal trends in nutrient ratios: chemical evidence of Mediterranean ecosystem changes driven by human activity. Deep-Sea Res. II 49, 2007-2016.

[10] Bonnet, S., Grosso, O., Moutin, T., 2011. Planktonic dinitrogen fixation alog a longitudinal gradient across the Mediterranean Sea during the stratified period (BOUM cruise). Biogeosciences 8, 2257-2267, doi:10.5194/bg-8-2257-2011.

[11] Bosc, E., A. Bricaud, and D. Antoine (2004), Seasonal and interannual variability in algal 
biomass and primary production in the Mediterranean Sea, as derived from 4 years of SeaWiFS observations. Global Biogeochem. Cycles 18, GB1005, doi:10.1029/2003gb002034.

[12] Brad, W., Taylor, Keep, C.F., Hall, Jr., R.O., Koch, B.J., Tronstad, L.M., Flecker, A.S., Ulseth, A.J., 2007. Improving the fluorometric ammonium method: matrix effects, background fluorescence, and standard additions J.N. Am. Benthol. Soc. 26, 2, 167-177.

[13] Chester, R., Nimmo, M., Corcoran, P.A., 1997. Rainwater-aerosol trace metal relationships at Cap Ferrat: a coastal site in the Western Mediterranean. Mar. Chem. 58, 293-312.

[14] Christodoulaki, S., Petihakis, G., Kanakidou, M., Mihalopoulos, N., Tsiaras, K., Triantafyllou, G., 2013. Atmospheric deposition in the Eastern Mediterranean. A driving force for ecosystem dynamics. J. Mar. Syst. 109:78-93, doi:10.1016/j.jmarsys.2012.07.007.

[15] Copin-Montégut, C., 2000. Consumption and production on scales of a few days of inorganic carbon, nitrate and oxygen by the planktonic community: results of continuous measurements at the DYFAMED Station in the northwestern Mediterranean Sea (May 1995). Deep-Sea Res. I 47, 447477.

[16] Cuypers, Y., Bouruet-Aubertot, P., Marec, C., Fuda, J.L., 2012. Characterization of turbulence from a fine-scale parametrization and microstructure measurements in the Mediterranean Sea during the BOUM experiment. Biogeosciences 9, 3131-3149, doi:10.5194/bg-9-3131-2012.

[17] Diaz, F., Raimbault P., 2001. Early spring phosphorus limitation of primary productivity in a NW Mediterranean coastal zone (Gulf of Lions). Mar. Ecol. Progr. Ser. 211, 51-62, doi:10.3354/meps211051.

[18] D’Ortenzio, F., Iudicone, D., de Boyer Montegut, C., Testor, P., Antoine, D., Marullo, S., Santoleri, R., Madec, G., 2005. Seasonal variability of the mixed layer depth in the Mediterranean Sea as derived from in situ profiles. Geophys. Res. Lett. 32, L12605, doi:10.1029/2005GL022463.

[19] D'Ortenzio, F., Ribera d'Alcalà, M.R., 2009. On the trophic regimes of the Mediterranean Sea: a satellite analysis, Biogeosciences 6, 2, 139-148. 
[20] Duce, R., LaRoche J., Altieri K., Arrigo K., Baker A., Capone D., Cornell S., Dentener F., Galloway J., Ganeshram R., 2008. Impacts of atmospheric anthropogenic nitrogen on the open ocean. Science 320(5878), 893-897.

[21] Durrieu de Madron, X., et al., 2011. Marine ecosystems' responses to climatic and anthropogenic forcings in the Mediterranean. Progr. Oceanogr. 91, 2, 97-166.

[22] Dyhrman, S.T., Chappell, P.D., Haley, S.T., Moffett, J.W., Orchard, E.D., Waterbury, J.B., Webb, E.A., 2006. Phosphonate utilization by the globally important marine diazotroph Trichodesmium. Nature 439, 5, 68-71, doi:10.1038/nature04203.

[23] Gačić, M., Civitarese, G., Miserocchi, S., Cardin, V., Crise, A., Mauri, E., 2002. The openocean convection in the Southern Adriatic: A controlling mechanism of the spring phytoplankton bloom. Cont. Shelf Res. 22, 14, 1897-1908, doi:10.1016/S0278-4343(02)00050-X.

[24] Garcia, N., Raimbault, P., Gouze, E., Sandroni, V., 2006. Dinitrogen fixation and primary production in Western Mediterranean Sea. C. R. Acad. Sci. 329, 9, 742-750.

[25] Guerzoni, S., Chester, R., Dulac, F., Herut, B., Loÿe-Pilot., M.D., Measures, C., Migon, C., Molinaroli, E., Moulin, C., Rossini, P., Saydam, C., Soudine, A, Ziveri, P., 1999. The role of atmospheric deposition in the biogeochemistry of the Mediterranean Sea. Progr. Oceanogr. 44, 1-3, 147-190.

[26] Guieu, C., Aumont, O., Paytan, A., Bopp, L., Law, C.S., Mahowald, N., Achterberg, E.P., Marañon, E., Salihoglu, B., Crise, A., Wagener, T., Herut, B., Desboeufs, K., Kanakidou, M., Olgun, N., Peters, F., Pulido-Villena, E., Tovar-Sanchez, A., Volker, C., 2014. The significance of the episodic nature of atmospheric deposition to Low Nutrient Low Chlorophyll regions. Global Biogeochem. Cycles 28, 11, 1179-1198, doi:10.1002/2014GB004852.

[27] Hampel, F.R., Ronchetti, E.M., Rousseeuw, P.J., Stahel, W.A., 2011. Robust statistics: The approach based on influence functions (Eds.) F.R. Hampel, E.M. Ronchetti, P.J. Rousseeuw, and W.A. Stahel, pp. 465, John Wiley \& Sons, Hoboken, NJ, USA.

[28] Heimbürger, L.E., Lavigne, H., Migon, C., D'Ortenzio, F., Estournel, C., Coppola, L., Miquel, J.C., 2013. Temporal variability of vertical export flux at the DYFAMED time-series station 
doi:10.1016/j.pocean.2013.08.005.

[29] Heimbürger, L.E., Migon, C., Cossa, D., 2011. Quantification of trace metal enrichments of Ligurian surface waters by atmospheric deposition: A box model assessment. Environ. Pollut. 159, 1629-1634, doi:10.1016/j.envpol.2011.02.046.

[30] Heimbürger, L.E., Migon, C., Losno, R., Miquel, J.C., Thibodeau, B., Stabholz, M., Dufour, A., Leblond, N., 2014. Vertical export flux of metals in the Mediterranean Sea. Deep-Sea Res. I 87, 14-23.

[31] Herrmann, M.J., Somot, S., 2008. Relevance of ERA40 dynamical downscaling for modelling deep convection in the Mediterranean Sea. Geophys. Res. Lett. 35, 4, L04607.

[32] Herrmann M.J., Somot S., Sevault F., Estournel C., Déqué, M., 2008. Modeling the deep convection in the northwestern Mediterranean Sea using an eddy-permitting and an eddy-resolving model: Case study of winter 1986-1987. J. Geophys. Res. 113, C04011, doi:10.1029/2006JC003991.

[33] Herut, B., Krom, M.D., Pan, G., Mortimer, R., 1999. Atmospheric input of nitrogen and phosphorus to the Southeast Mediterranean: sources, fluxes and possible impact. Limnol. Oceanogr. 44, 1683-1692.

[34] Holmes, R.M., Aminot, A., Kérouel, R., Hooker, B.A., Peterson, B.J., 1999. A simple and precise method for measuring ammonium in marine and freshwater ecosystems. Can. J. Fish. Aquat. Sci. 56, 1801-1808.

[35] Ibello, V., Cantoni, C., Cozzi, S., Civitarese, G., 2010. First basin-wide experimental results on $\mathrm{N}_{2}$ fixation in the open Mediterranean Sea. Geophys. Res. Lett. 37, L03608, doi:10.1029/2009GL041635.

[36] Johannes, R.E. 1964. Uptake and release of dissolved organic phosphorus by representatives of a coastal marine ecosystem. Limnol. Oceanogr. 9, 224-234.

[37] Johnson, K.S., Coletti, L.J., Chavez, F.P., 2006. Diel nitrate cycles observed with in situ 
sensors predict monthly and annualnew production. Deep-Sea Res I 53, 3, 561-573.

[38] Johnson KS, Coletti LJ, Jannasch HW, Sakamoto CM, Swift DD, Riser SC (2013) Long-term nitrate measurements in the ocean using the In Situ Ultraviolet Spectrophotometer: sensor integration into the APEX profiling float. $\mathrm{J}$ Atmos Ocean Technol 30, 8, 1854-1866, doi: 10.1175/JTECH-D-12-00221.1.

[39] Kanakidou, M., Duce, R.A., Prospero, J.M., Baker, A.R., Benitez-Nelson, C., Dentener, F.J., Hunter, K.A., Liss, P.S., Mahowald, N., Okin, G.S., Sarin, M., Tsigaridis, K., Uematsu, M., Zamora, L.M., Zhu, T., 2012. Atmospheric fluxes of organic N and P to the global ocean. Global Biogeochem. Cycles 26, GB3026, doi:10.1029/2011GB004277.

[40] Karl, D.M., Yanagi, K., 1997. Partial characterization of the dissolved organic phosphorus pool in the oligotrophic North Pacific Ocean. Limnol. Oceanogr. 42, 6, 1398-1405.

[41] Krishnamurthy, A., Moore, J.K., Mahowald, N., Luo, C., Zender, C.S., 2010. Impacts of atmospheric nutrient inputs on marine biogeochemistry. J. Geophys. Res. 115, G01006, doi:10.1029/2009JG001115.

[42] Krom, M.D., Emeis,K.C., Van Cappellen, P., 2010. Why is the Eastern Mediterranean phosphorus limited ? Progr. Oceanogr. 85, 236-244.

[43] Krom, M.D., Herut, B., Mantoura, R.F.C., 2004. Nutrient budget for the Eastern Mediterranean: implications for phosphorus limitation. Limnol. Oceanogr. 49, 1582-1592.

[44] Large W.G., Yeager, S.G., 2004: Diurnal to decadal global forcing for ocean and sea-ice models: the data sets and flux climatologies. NCAR Technical Note NCAR/TN-460+STR, doi: 10.5065/D6KK98Q6.

[45] Lionello, P., Malanotte-Rizzoli, P., Boscolo, R., Alpert, P., Artale, V., Li, L., Luterbacher, J., May, W., Trigo, R., Tsimplis, M., Ulbrich, U., Xoplaki, E., 2006. The Mediterranean climate: An overview of the main characteristics and issues. In: The Mediterranean Climate Variability, (Ed.) P. Lionello, P. Malanotte-Rizzoli, and R. Boscolo, pp. 126, Elsevier, Amsterdam, The Netherlands.

[46] Loÿe-Pilot, M.D., Martin, J.M., Morelli, J., 1990. Atmospheric input of inorganic nitrogen to 
[47] Ludwig, W., Dumont, E., Meybeck, M., Heussner, S., 2009. River discharges of water and nutrients to the Mediterranean and Black Sea: Major drivers for ecosystem changes during past and future decades? Progr. Oceanogr. 80,199-217, doi:10.1016/j.pocean.2009.02.001.

[48] Mahowald, N., Jickells, T.D., Baker, A.R., Artaxo, P., Benitez-Nelson, C.R., Bergametti, G., Bond, T.C., Chen, Y., Cohen, D.D., Herut, B., Kubilay, N., Losno, R., Luo, C., Maenhaut, W., McGee, K.A., Okin, G.S., Siefert, R.L., Tsukuda, S., 2008. Global distribution of atmospheric phosphorus deposition and anthropogenic impacts. Global Biogeochem. Cycles 22, GB4026, doi:10.1029/2008GB003240.

[49] Markaki, Z., Löye-Pilot, M.D., Violaki, K., Benyahya, L., Mihalopoulos, N., 2010. Variability of atmospheric deposition of dissolved nitrogen and phosphorus in the Mediterranean and possible link to the anomalous seawater N/P ratio. Mar. Chem. 120, 187-194, doi:10.1016/j.pocean.2009.02.001.

[50] Markaki, Z., Oikonomou, K., Kocak, M., Kouvarakis, G., Chaniotaki, A., Kubilay, N., Mihalopoulos, N., 2003. Atmospheric deposition of inorganic phosphorus in the Levantine Basin, eastern Mediterranean: spatial and temporal variability and its role in seawater productivity. Limnol. Oceanogr. 48, 1557-1568.

[51] Marsaleix P., Auclair F., Duhaut T., Estournel C., Nguyen C., C. Ulses, 2012. Alternatives to the Robert-Asselin filter. Ocean Model. 41, 53-66. doi:10.1016/j.ocemod.2011.11.002

[52] Marsaleix P., Auclair, F. Estournel, C., 2009. Low-order pressure gradient schemes in sigma coordinate models: The seamount test revisited. Ocean Model. 30, 169-177, doi:10.1016/j.ocemod.2009.06.011.

[53] Marsaleix, P., Auclair, F., Floor, J.W., Herrmann, M.J., Estournel, C., Pairaud, I., Ulses, C., 2008. Energy conservation issues in sigma-coordinate free-surface ocean models. Ocean Model. 20, 1, 61-89, doi:10.1016/j.ocemod.2007.07.005.

[54] Marty, J.C., Chiaverini J., 2002. Seasonal and interannual variations in phytoplankton production at DYFAMED time-series station, Northwestern Mediterranean Sea. Deep-Sea Res. II 
[55] Marty, J.C., Chiaverini, J., Pizay, M.D., Avril, B., 2002. Seasonal and interannual dynamics of nutrients and phytoplankton pigments in the wester Mediterranean Sea at the DYFAMED timeseries station (1991-1999). Deep-Sea Res. II 49, 1965-1885.

[56] Migon, C., 1993. Riverine and atmospheric inputs of heavy metals to the Ligurian Sea. Sci. Total Environ. 138, 289-299.

[57] Migon, C., Copin-Montégut, G., Elégant, L., Morelli, J., 1989. Etude de l'apport atmosphérique en sels nutritifs au milieu coôtier méditerranéen et implications biogéochimiques. Oceanol. Acta 12, 187-191.

[58] Migon, C., Robin, T., Dufour, A., Gentili, B., 2008. Decrease of lead concentrations in the western Mediterranean atmosphere during the last twenty years. Atmos. Environ. 42, 815-821, doi:10.1016/j.atmosenv.2007.10.078.

[59] Migon, C., Sandroni, V., Béthoux, J.P., 2001. Atmospheric input of anthropogenic phosphorus to the northwest Mediterranean during the oligotrophic season. Marine Environmental Research 52, 5, 413-426.

[60] Migon, C., Sandroni, V., Marty, J.C., Gasser, B. \& Miquel, J.C. (2002) Transfer of atmospheric matter through the euphotic layer in the northwestern Mediterranean: seasonal pattern and driving forces. Deep-Sea Res. II 49, 11, 2125-2142.

[61] Moore, R.M., Milley, J.E., Chatt, A., 1984. The potential for biological mobilization of trace elements from aeolian dust in the ocean and its importance in the case of iron. Oceanol. Acta 7, $221-228$.

[62] Moulin, C., Lambert, C.E., Dulac, F., Dayan, U., 1997. Control of atmospheric export of dust from North Africa by the North Atlantic oscillation. Nature 387, 691-694.

[63] Moutin, T., Raimbault, P., 2002. Primary production, carbon export and nutrient availability in eastern and western Mediterranean Sea in early summer. J. Mar. Syst. 273-288. 
[64] Niewadomska, K., Claustre, H., Prieur, L., D'Ortenzio, F., 2008. Submesoscale physicalbiogeochemical coupling across the Ligurian current (northwestern Mediterranean) using a biooptical glider. Limnol. Oceanogr. 53, 2210-2225.

[65] Okubo, A., 1971. Horizontal and vertical mixing in the sea. In: Impingement of Man in the Oceans, (Ed.) D.W. Hood, pp. 89-168, John Wiley \& Sons, New York.

[66] Organelli, E., Bricaud, A., Antoine, D., Matsuoka, A., 2014. Seasonal dynamics of light absorption by chromophoric dissolved organic matter (CDOM) in the NW Mediterranean Sea (BOUSSOLE site). Deep-Sea Res. I 91: 72-85, doi:10.1016/j.dsr.2014.05.003.

[67] Pantoja, S., Repeta, D.J., Sachs, J.P., Sigman, D.M., 2002. Stable isotope constraints on the nitrogen cycle of the Mediterranean Sea water column. Deep-Sea Res. I 49:1609-1621.

[68] Pasqueron de Fommervault, O., Migon, C., D’Ortenzio, F., Riberad'Alcalà, M., Coppola, L., 2015. Temporal variability of nutrient concentrations in the northwestern Mediterranean Sea (DYFAMED time-series station). Deep-Sea Res. I 100, 1-12.

[69] Pulido-Villena, E., Rerolle, V., Guieu, C., 2010. Transient fertilizing effect of dust in Pdeficient LNLC surface ocean. Geophys. Res. Lett. 37, L01603, doi:10.1029/2009GL041415.

[70] Raimbault, P., Slawyk, G., Coste, B., Fry, J., 1990. Feasibility of using an automated colorimetric procedure for the determination of seawater nitrate in the 0 to $100 \mathrm{nM}$ range: Examples from field and culture. Mar. Biol. 104: 347-351.

[71] Redfield, A.C., 1934. On the proportions of organic derivations in seawaterand their relation to the composition of plankton. In: Daniel, R.J. (Ed.), James Johnstone Memorial Volume. University Press of Liverpool, Liverpool (UK), pp. 177-192.

[72] Ribera d'Alcalà, M., Civitarese, G., Conversano, F., Lavezza, R., 2003. Nutrient ratios and fluxes hint at overlooked processes in the Mediterranean Sea. J. Geophys. Res. 108, C9, 8106, doi:10.1029/2002JC001650.

[73] Sachs, J.P., Repeta, D.J., 1999. Oligotrophy and nitrogen fixation during eastern Mediterranean sapropel events. Science 286, 2485-2488. 


\section{ACCEPTED MANUSCRIPT}

[74] Sandroni, V., Migon, C., 1997. Significance of trace metal medium-range transport in the western Mediterranean. Sci. Total Environ. 196, 83-9.

[75] Sandroni, V., Raimbault, P., Migon, C., Garcia, N., Gouze, E., 2007. Dry atmospheric deposition and diazotrophy as sources of nitrogen to northwestern Mediterranean oligotrophic surface waters. Deep-Sea Res. I 54:1859-1870.

[76] Santinelli, C., Ibello, V., Lavezza, R., Civitarese, G., Seritti, A., 2012. New insights into C, N, and P stoichiometry in the Mediterranean Sea: The Adriatic Sea case. Cont. Shelf Res. 44, 83-93, doi:10.1016/j.csr.2012.02.015.

[77] Severin, T., Conan, P., Durrieu de Madron, X., Houpert, L., Oliver, M.J., Oriol, L., Caparros, J., Ghiglione, J.F., Pujo-Pay, M., 2014. Impact of open-ocean convection on nutrients, phytoplankton biomass and activity. Deep-Sea Res. I 94, 62-71, doi:10.1016/j.dsr.2014.07.015.

[78] Turley, C.M., 1999. The changing Mediterranean Sea - a sensitive ecosystem. Progr. Oceanogr. 44, 387-400.

[79] Van Wambeke, F., Christaki, U., Giannakourou A., Moutin, T., Souvemerzoglou, K., 2002. Longitudinal and vertical trends of bacterial limitation by phosphorus and carbon in the Mediterranean Sea. Microb. Ecol. 43, 119-133.

[80] Violaki, K., Zarbas, P., Mihalopoulos, N., 2010. Long-term measurements of water soluble organic nitrogen (WSON) in atmospheric deposition in the Eastern Mediterranean: fluxes, origin and biogeochemical implications, Mar. Chem. 120, 179-186, doi:10.1016/j.marchem.2009.08.004. wambeke.

[81] Violaki, K., Sciare, J., Williams, J., Baker, A.R., Martino, M. Mihalopoulos, N., 2015. Atmospheric water-soluble organic nitrogen (WSON) over marine environments: a global perspective. Biogeosciences 12, 10, 3131-3140, doi: 10.5194/bg-12-3131-2015.

[82] Volpe, G., Banzon, V.F., Evans, R.H., Santoleri, R., Mariano, A.J., Sciarra, R., 2009. Satellite observations of the impact of dust in a low-nutrient, low-chlorophyll region: Fertilization or artifact? Global Biogeochem. Cycles 23, GB3007, doi:10.1029/2008GB003216. 


\section{ACCEPTED MANUSCRIPT}

[83] Y1lmaz, A., Tugrul, S., 1998. The effect of cold- and warm-core eddies on the distribution and stoichiometry of dissolved nutrients in the northeastern Mediterranean. J. Mar. Syst. 16,253-268.

[84] Yogev, T., Rahav, E., Bar-Zeev, E., Man-Aharonovich, D., Stambler, N., Kress, N., Béjà, O., Mulholland, M.R., Herut, B., Berman-Frank, I., 2011. Is dinitrogen fixation significant in the Levantine Basin, East Mediterranean sea? Environ. Microbiol. 13, 4, 854-871, doi:10.1111/j.14622920.2010.02402.

\section{Highlights}

- Nitrogen atmospheric fluxes are more controlled by the wet mode

- Nitrate is more deposited under dry form, ammonia under wet form

- Phosphorus atmospheric fluxes are more controlled by the dry mode

- Atmospheric deposition strongly impacts Mediterranean molar ratios N/P

- Atmosphere supplies more nutrients to surface waters than diazotrophy or diffusion 